\title{
Lexis
}

Journal in English Lexicology

$14 \mid 2019$

Blending in English

\section{A corpus-based analysis of new English blends}

\section{Mattiello Elisa}

\section{(2) OpenEdition}

\section{Journals}

Electronic version

URL: http://journals.openedition.org/lexis/3660

DOI: $10.4000 /$ lexis.3660

ISSN: 1951-6215

\section{Publisher}

Université Jean Moulin - Lyon 3

\section{Electronic reference}

Mattiello Elisa, "A corpus-based analysis of new English blends », Lexis [Online], 14 | 2019, Online since 16 December 2019, connection on 20 April 2020. URL : http://journals.openedition.org/lexis/ 3660 ; DOI : https://doi.org/10.4000/lexis.3660

This text was automatically generated on 20 April 2020.

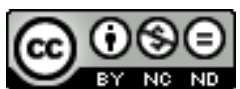

Lexis is licensed under a Creative Commons Attribution-NonCommercial-NoDerivatives 4.0 International License. 


\title{
A corpus-based analysis of new English blends
}

\author{
Mattiello Elisa
}

\section{Introduction}

[A]ll speech, smooth as well as blunderful, can be and must be accounted for essentially in terms of the three mechanisms... analogy, blending, and editing. [Hockett 1967: 935]

1 Lexical blending is a widely discussed topic in morphological literature. It has recently attracted the attention of several scholars, who have focused on 1) the role of prosodic structure in the formation of new English blends [Arndt-Lappe \& Plag 2013], 2) prototypical blend features [Bauer 2012] and regularities in blend formation [Mattiello 2013], 3) the relationship between blend structure and meaning [Beliaeva 2014], and 4) the interpretation and acceptability of new lexical blends [Connolly 2013]. Lexical blending has also been studied from a cross-disciplinary perspective, in a volume collecting data from typologically different languages [Renner, Maniez \& Arnaud 2012].

2 This paper investigates new lexical blends in English, their frequency, pragmatic contexts, and functions, as well as the emergence of new splinters in their formation. In particular, the paper analyzes a collection of 245 blends from quantitative and qualitative viewpoints. The approach is both data-driven and corpus-based. For the analysis, the study uses lexicographic information drawn from the online version of the Oxford English Dictionary [OED2-3], as well as corpora of English, i.e. Corpus of Contemporary American English [COCA] and News on the Web corpus [NOW]. The data has been collected through an advanced search in the OED and covers a time span (1950-2010) which testifies to the current relevance and increasing incidence of the blending process as a word-formation mechanism for the creation of new words in English. The OED indeed shows that the number of new entries created by blending doubles in intervals of fifty years, namely, 33 instances in 1800-1850, 65 in 1850-1900, 147 in 1900-1950, and 246 in 1950-2000, as shown in Figure 1. 
Figure 1: Advanced search results for 'blend' in the OED

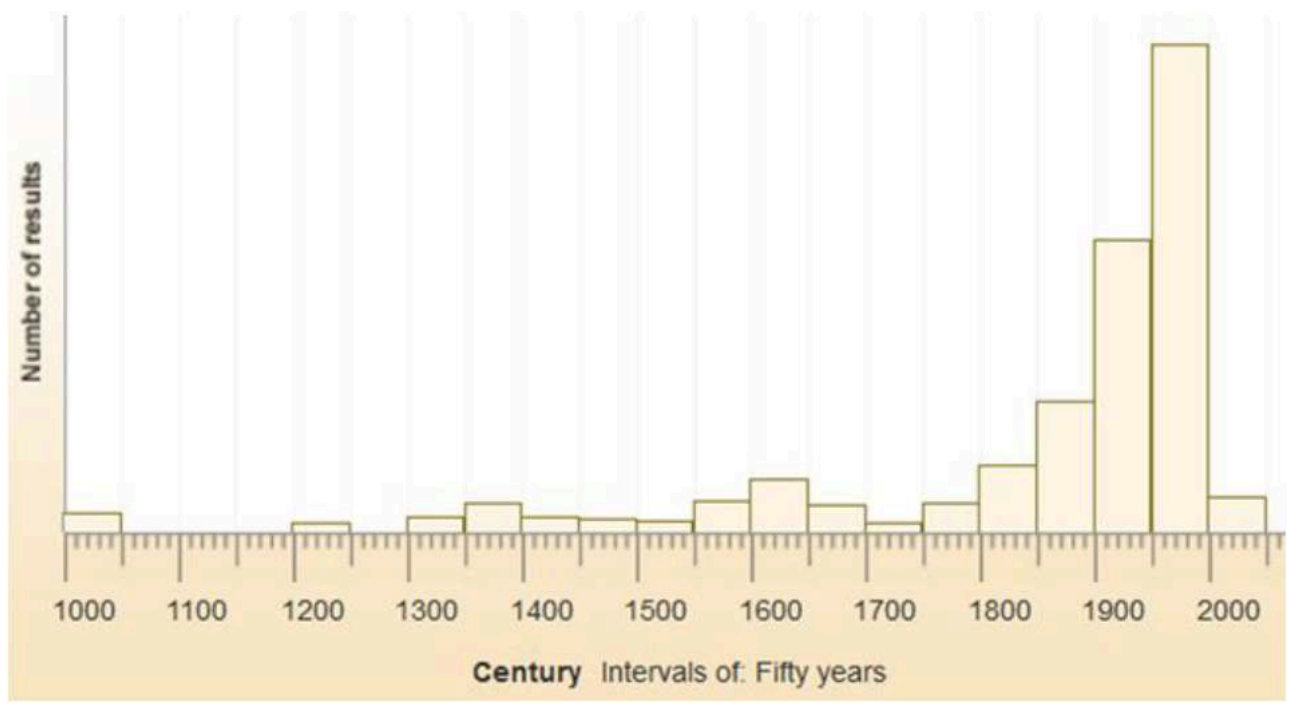

The database of the study includes both "nonce formations" [Bauer 1983: 45; or “occasionalisms”, Chanpira 1966 in Dressler \& Tumfart 2017: 155-156], which are coined for specific textual/stylistic purposes, and more stable neologisms, which are already or are likely to become a permanent part of the English lexicon (cf. "lexicalization" and "institutionalization" in Brinton \& Traugott [2005: 45]). However, the attention is especially focused on neologisms, which from a quantitative viewpoint are more frequent and, from a qualitative viewpoint, can better illustrate the contexts motivating blending and the functions that new English blends can fulfil.

The goal of the study is fourfold:

1. First, it aims at identifying the contexts/registers which favour the formation of blend words, ranging from slang/colloquial registers (e.g. bromance $\leftarrow$ bro + romance) to specialized domains. While the semantically hybrid nature of blending has been stressed in the literature - e.g., it is used to form names for unions, alloys, companies, etc. [Thornton 1993, 2004; Renner 2006; Bauer 2012] - and this process has often been regarded as a mechanism used to gain our attention in the media and advertising [Lehrer 2007; Ronneberger-Sibold 2010], its relevance to specialized vocabulary has not been adequately remarked hitherto. Pertinent domains for blends include, for instance, business (adhocracy $\leftarrow$ ad hoc + bureaucracy), economics (stagflation $\leftarrow$ stagnation + inflation), electronics (rectenna $\leftarrow$ rectifying + antenna), technology (phablet $\leftarrow$ phone + tablet), etc.

2. Second, this study addresses the question of whether blends are created with the intention of designating a new referent, thus filling in a conceptual/lexical gap, or to give a new name to an existing referent, as an act of economizing or creating a stylistic effect. For instance, the blend jeggings ( $\leftarrow$ jeans + leggings) has been recently coined to designate 'tight-fitting stretch leggings for women, styled to resemble a pair of denim jeans', and it has even become a proprietary name in the United Kingdom. By contrast, vodkatini and surfari are merely shorter words for existing concepts expressed by compounds, i.e. vodka martini ('a martini cocktail in which vodka is substituted for gin') and surf safari ('a journey made by surfers in search of good conditions for surfing'). The fact that only $4.9 \%$ of the blends in our database fall in the latter group confirms the necessity of blending as a word-formation mechanism used to label new complex concepts or objects, fusions, amalgams, and, more rarely, qualities or actions.

3. Third, the study focuses on a particular type of blending, called 'attributive' or 'headed', such as rockumentary $(\leftarrow$ rock + documentary $)$, eatertainment $(\leftarrow$ eat + entertainment $)$, and 
Clintonomics $(\leftarrow$ Clinton + economics). Attributive blends exhibit an "endocentric relation" with their head [Bat-El 2006: 67], which therefore has a greater semantic weight than the first component (i.e. the modifier).

4. In particular, in this study, we will address the issue of attributive blends as possible schema model for new blends, with the second splinter (e.g. -umentary, -tainment, and -(o)nomics) as potential combining form, or secreted affix [Fradin 2000], for novel formations.

Issues 2 to 4 also question the boundaries between blending and clipped compounding [Beliaeva 2014], as well as between blending and frequent splinters, combining forms, or secreted affixes [Mattiello 2018].

\section{Theoretical background}

\subsection{Definition and classification of blending}

Linguists generally agree on the definition of lexical blending as the merging of two (or more) lexemes into one involving partial loss of the phonological and/or graphic material of at least one of them, as in smaze $\leftarrow s m($ oke $)+($ h)aze, with partial drop of both source words. Frequently, there is an overlap between the source words, as in boatel $\leftarrow$ boat + hotel, with overlap of the phonemes /əut/ which favours the fusion. Connolly [2013:3] respectively calls these two types "substitution blends" and "overlap blends".

7 A different terminological distinction is provided by Ronneberger-Sibold [2006: 155], who classifies blends according to their degree of transparency, from very transparent "telescope blends" (e.g. G. Amtsschimmelpilz 'red tape fungus' $\leftarrow$ Amtsschimmel + Schimmelpilz) to completely opaque "fragment blends" (e.g. Cujasuma 'a brand of tobacco' $\leftarrow$ Cuba + Java + Sumatra). Three-member blends are infrequent in English (an example is turducken 'a poultry dish' $\leftarrow$ turkey + duck + chicken).

Finally, we can classify blends according to a semantic criterion, differentiating the 'coordinate' type (frenemy is both 'friend' and 'enemy') from the 'headed' or 'attributive' type (e.g. slimnastics is 'gymnastics that slim you down'). In the headed type, the right constituent (gymnastics) acts as head and therefore carries a greater semantic weight than the left one (slimming).

\subsection{Blends vis-à-vis other morphological categories}

While different labels and classifications abound in the literature, scholars also disagree on the distinction between blends and other neighbouring morphological categories, especially clipped compounds (e.g. froyo $\leftarrow$ frozen yogurt) and secreted affixes (e.g. -aholic $\leftarrow$ alcoholic in shopaholic). It is often remarked that blending can be compared to compounding because it combines two (or more) base lexemes in order to form a new one [Bauer \& Huddleston 2002: 1636; Gries 2004: 639]. However, whereas compounding is generally regarded as a regular, productive process, blending is viewed as "irregular and unpredictable" [Connolly 2013: 3]. This is mainly due to the fact that compounding combines words, whereas blending combines word parts [Kemmer 2003: 75] and its output is not regularly and transparently analyzable into morphemes [Bauer 1983: 234]. 
10 This difficulty in identifying regularities in blends has led Laurie Bauer to list prototypical phonological, structural and semantic features as "defeasible constraints" for blends' description, i.e. discriminating between the core and the periphery of blends, thereafter concluding that "the category is a fuzzy one" [Bauer 2012:11, 21; cf. formal, semantic and syntactic properties in Cannon 2000]. Bat-El [2006: 66], instead, provides a narrow definition of blends, which according to her "refer only to cases where the inner edges are truncated" (e.g. Oxbridge $\leftarrow$ Ox(ford) $+($ Cam)bridge, jazzercise $\leftarrow$ jazz + (ex)ercise). This definition excludes from the category of blending forms where the right edges of two words are truncated (e.g. sitcom $\leftarrow$ sit(uation) $+\operatorname{com}($ edy)) or where only the first word undergoes truncation (e.g. mocamp $\leftarrow$ mo(tor) + camp), which rather belong to the category of clipped compounds [Bat-El 2006]. In general, a clipped compound differs from a blend because it is attested as compound before being shortened. Thus, while *jazz exercise is not attested in this full form, only the blend jazzercise [1976] is, sitcom [1964] is shortened from the compound situation comedy [1953] and mocamp [1967] is a clipped compound from motor camp [1925]. ${ }^{1}$

11 In this paper, we do not adopt Bat-El's narrow definition, but rather extend blending to a broader category which also includes the 'intercalative' type (e.g. ambisextrous, where sex is intercalated within ambi(dex)drous) [Kemmer 2003: 72] and the type obtained from two word beginnings (e.g. modem $\leftarrow$ mo(dulator) + dem(odulator)), although these are rarer than the prototypical type merging the beginning of one word with the end of another (e.g. gasohol $\leftarrow$ gas(oline) $+($ alc)ohol). The only restriction for blends seems to be that "the beginning of a blend cannot be the end of a word, e.g. *glyson for "ugly person'." [Lehrer 1996: 364] (however, cf. the clipped compound blog $\leftarrow$ weblog).

12 Another fundamental distinction is between blending and combining forms (or secreted affixes). Fradin [2000:46-47], for instance, has provided criteria to discriminate between these two morphological categories. Phonologically, combining forms are obtained by shortening the beginning or the end of a lexeme (e.g. -ware $\leftarrow$ (soft)ware in freeware, or eco- $\leftarrow$ eco(logy) in ecotourism), whereas there are numerous patterns in blend formation (as shown above). Semantically, while in blends the semantic content of the components is kept intact, in secreted affixation some semantic elements are kept and others discarded (cf. "secretion" vs. "abbreviation" in Warren [1990: 119]). Thus, boatel 'boat which functions as a hotel' is a blend, while shopaholic 'compulsive shopper' is a secreted formation obtained by discarding the semantic element 'alcohol' from alcoholic. Therefore, secreted affixing also involves abstraction - i.e. -(a)holic conveys the meaning 'person addicted to the thing, activity, etc., expressed by the first element' (e.g. shopping) - while blending does not.

The distinction between compounds, combining forms, and blends leads us to a more general tripartition which is elaborated within the framework of Natural Morphology (esp. in Dressler [2000]), i.e. "grammatical" vs. "marginal" vs. "extra-grammatical" morphology. In this framework, compounds like situation comedy belong to grammatical morphology because they are regularly formed according to word-formation rules and their outputs are fully predictable from their inputs (in this case, [situation $]_{\mathrm{N}}+$ $[\text { comedy }]_{\mathrm{N}}$ ). Combining forms like $-($ a)holic instead belong to marginal (but still grammatical) morphology, in that they are non-prototypical (i.e. at the boundaries) of morphology [Dressler 2000:6-7]. In particular, they are transitional between two subcomponents of morphology (i.e. derivation and compounding), depending on whether we consider combining forms to be bound or free morphemes. In the OED, for 
instance, -(a)holic is labelled "suffix" and the outputs foodaholic, newsaholic, shopaholic, spendaholic, workaholic, etc. are regularly created from it. Finally, blending, like clipped compounding (the sitcom type), is a creative technique which Ronneberger-Sibold [2010: 201] includes among "intentional extragrammatical operations", as opposed to "unintentional" ones occurring, e.g., during first language acquisition or in speecherrors. The use of extra-grammatical operations for the creation of new lexemes is termed "word creation" by Ronneberger-Sibold [2010: 201], as opposed to regular word-formation. Accordingly, blending is viewed as part of word-creation, rather than as a regular process of word-formation. For example, blends like smaze and boatel are dismissed from morphological grammar because their input does not allow a prediction of a regular output like rules do, or their output is only partially predictable on account of some sub-regularities or preferences for prototypicality [Mattiello 2013].

However, a subtler distinction should be made between new blends that are single formations created after a model word - e.g., boatel is created after the model of motel $(\leftarrow$ motor + hotel $)$ - and new blends that follow a schema model. Indeed, there are some blend "splinters" [Lehrer 1996, 2007] which recur frequently in novel coinages, thus showing a tendency towards regularity [Mattiello 2018] and productivity [Plag 1999; Bauer 2001; Bauer et al. 2013]. For instance, attributive blends such as eatertainment, irritainment, and shoppertainment exhibit a splinter -tainment (shortened from entertainment) which is also found in earlier docutainment, edutainment, and infotainment.

In the present study, new blends with recurring splinters such as -tainment are included within "paradigmatic morphology" [Bauer et al. 2013], in that they suggest an analysis in terms of paradigmatic substitution or analogy. In particular, while boatel belongs to "surface analogy", based on a unique model, eatertainment and the like belong to "analogy via schema", with a set of prototype words as model [Mattiello 2017; see "schema" in Köpcke 1993; cf. "schemas" and "subschemas" within Booij's 2010 Construction Morphology]. In this study, the delimitation between productive and unproductive splinters in blending will be supported by a corpus investigation.

\subsection{Contexts and recognition of new lexical blends}

Another issue which will be addressed in this paper concerns the contexts where new English blends are created and employed, as well as their naming function, especially in specialized domains. In the literature, Thornton [1993: 148] has claimed that in Italian "[t]he formation of blends is scarcely productive", mainly limited to designate entities such as companies, associations, unions, alloys, synthetic textiles, chemicals, and hybrids in general. She added that the creation of blends is favoured by the iconicity principle of Natural Morphology: i.e., the mixture of alloys, chemicals, etc. (signatum) is iconically reflected by the mixture in the process of formation of their names (signans). This favours the use of blends with a labelling function.

Similar conclusions are drawn by Ronneberger-Sibold [2006: 161] for German: "a strong formal amalgamation of the blended words can mirror a corresponding fusion of their referents". For instance, substances consisting of several amalgamated ingredients are iconically named by amalgamated nouns, such as the blend smog $\leftarrow$ smoke + fog. In her view, this iconicity is chiefly illustrated by brand names, which are generally created to impress listeners, and by pharmaceutical products, which often have scientific names reminiscent of the chemicals making them up. Ronneberger-Sibold [2010: 206-207] also 
claims that, in general, word-creation is used in the realms of humorous literature - i.e. literature for children or texts for adults, whose aim is to amuse their listeners or readers - and of advertising, where the shape of a word can attract the attention of potential customers.

In a study on novel English blends, Lehrer [2007:128] has similarly remarked that "[t]he commonest places for blends to occur are in product names, advertisements, newspaper and magazine headlines and titles". According to her, the creation of blends is mainly motivated by the goal to call the reader's attention to the product, news item, etc. and elicit his/her favourable response, such as remembering the product name, buying it, reading the news piece, etc. However, Lehrer [2007: 129] also notes the ephemeral nature of most blends, which are often intended to be "nonce forms - items produced for a specific context and occasion". In connection with this, we assume that, while blends created in familiar, jocular or humorous contexts may be short-lived ad hoc creations, those formed in specialized contexts, such as pharmacy, biology, or information technology, are more stable formations that experts adopt for their efficiency (Language Economy Principle) and effectiveness (Iconicity Principle).

The demarcation line between 'nonce' blends (or occasionalisms) and proper 'neologisms', i.e. intended to enter the lexical stock of a language, is also related to the role of blending in lexical innovation and in the overall process of language change [Connolly 2013; cf. Milroy 1992; Brinton \& Traugott 2005]. While the frequent emergence of new lexical blends in English (Figure 1) suggests that blending is a common process for the creation of new linguistic material (innovation), the proliferation among wider groups of speakers (adoption) might not be homogeneous for all innovative lexical items. Experiments have demonstrated that there is no general consensus of the "adoptability" of innovative blends by native speakers [Connolly 2013: 3].

20 According to Connolly [2013: 12]:

The accessibility of the meaning of an innovative blend appears to play some role in whether or not it is adopted, but the perceived prestige and utility of the form must also be taken into account.

21 From this claim, we gather that the spread and recognition of lexical blends are mainly motivated by three factors. First, new lexical blends are widely accepted if their source lexemes are easily accessible (recognizable) and their meaning straightforwardly assigned. Second, their adoption is favoured by prestige, that is new lexical blends that are indicative of a prestigious norm of speech will be more likely to be adopted than those that are not. However, a substandard unit may also become lexicalized because it is amusing, humorous, or sarcastic. Third, new lexical blends are especially adopted if speakers perceive the utility of the form, e.g., to cover a conceptual or lexical gap in the language, or to produce a stylistic or textual effect.

In this paper, quantitative data will be used to 1) discriminate between nonce blends and blend neologisms, and 2) identify the preferential contexts and domains where blends are created, recognized, and adopted. Section 2 explains how data was collected and analyzed. 


\section{Data collection and method}

The data collected for this study was drawn from the online edition of the OED. For the selection of relevant data, the advanced search tool available on the OED platform was used. The parameters of selection were the formation process involved and the attestation date. First, the filter 'blend' in the etymology slot gave us 632 instances of blending in the overall dictionary (or, at least, those which have been labelled blends by lexicographers). Then, the entries were chronologically ordered from Early old English to the present time. This ordering showed that a substantial distribution of English blends especially occurred after 1950 (see Figure 1), although there were no contemporary examples dated after 2010. The filter '1950-today' restricted the set to 264 results, which appeared to be a representative collection of novel English blends for our goals. The collection was finally cleaned via close reading of each entry. Closer examination allowed us to exclude:

- Abbreviations from phrases: e.g., Amex $\leftarrow$ American Stock Exchange.

- Forms with affixes or combining forms: e.g., poofteroo $\leftarrow$ poofter + suffix -eroo, Neorican $\leftarrow$ neo- + Rican.

-Word parts: e.g., -bot $\leftarrow$ robot, -rific $\leftarrow$ terrific. Although some blends are obtained from these splinters (e.g. mobot $\leftarrow$ mobile + robot, yogarific $\leftarrow$ yoga + terrific), the blends which were not attested as separate entries in the OED were not included in the database, because they could not be retrieved systematically.

- Words whose origin is only analogical: e.g., outro is analogically coined after reanalysis of intro as a complex word in + tro, not a blend of out and intro.

-Words whose origin was uncertain: e.g., scuzz might be either an abbreviation from disgusting or a blend from scum and fuzz.

The final database consists of 245 English blends, including 209 nouns (85\%), 32 adjectives (13\%), and $4(1.6 \%)$ verbs. Among the nouns, 48 are spelt with initial capital letters. In other words, $23 \%$ of the nouns are proprietary or proper names. These percentages correspond to a scale of different referents and functions in blending formation:

Common nouns $65.7 \%>$ Names $19.6 \%$ > Adjectives $13 \%>$ Verbs $1.6 \%$

General denomination $>$ Labelling $>$ Description of qualities $>$ Reference to actions/

events.

Hence, preliminary quantitative results suggest that the denomination/labelling functions of blends prevail over the description of qualities or reference to actions. Needless to say, these results are also influenced by the larger size of the syntactic category of nouns vs. other word classes (verbs, adjectives, adverbs) in the English lexicon.

In addition, lexicographic examination provided useful information about 1) the register of the selected blends (esp. 'colloquial'/'slang' vs. specialized fields), 2) the status of the words (e.g. 'nonce-words', 'temporary words', only one 'historical'), and 3) the connotation of the words, sometimes described as 'derogatory', 'depreciative', 'humorous', or 'jocular'.

As for the methodology, a data-driven approach was combined with a corpus-based investigation. The corpora of English selected for the analysis are freely available at 
Brigham Young University website (http://corpus.byu.edu), where they were created by Mark Davies:

- Corpus of Contemporary American English [1990-2017, henceforth, COCA], which contains more than 560 million words with different genres of texts (spoken, fiction, popular magazines, newspapers, and academic) (last accessed April 2019);

- News on the Web Corpus [2010-present, henceforth, NOW], which contains 6.9 billion words of data from web-based newspapers and magazines (last accessed April 2019).

Given the different size of the two corpora, token frequencies were normalized for the quantitative goals. Both raw and per million word frequencies were checked for all blends in the two corpora. However, in frequency assessment, some occurrences had to be excluded because of their irrelevance to a study on blends. For instance, the ambiguity of the words chugger, faction, shim, and wuss gave many occurrences as results, both in COCA and in NOW, but not all of them corresponded to the blends in our database from, respectively, charity + mugger, fact + fiction, she + him, and wimp + puss. Other items excluded from quantitative results were personal names or names of companies in the corpora (Picon, Uniterm, Swingle, Skitch), which obviously did not match with the nouns picon $(\leftarrow$ picture + icon), uniterm $(\leftarrow$ unit + term), swingle $(\leftarrow$ swinging + single), and the verb skitch $(\leftarrow$ ski / skate + hitch $)$ in our database. Finally, the blend nerk ( $\leftarrow$ nerd + berk / jerk) was not included in counts because, in COCA, it only occurs as an acronym from 'Never Eat Road Kill', and occurrences of melded were rejected because they were past forms of meld instead of adjectives/past participles. For all of these reasons, the above-mentioned blends were not considered to discriminate between nonce formations and well-established neologisms.

In Section 3, results from quantitative investigation (\$3.1.) will be supported by a qualitative analysis of the data in its contexts of use (\$3.2.). Analogical blends and recurrent splinters will be considered in sub-section 3.3. A general discussion of results will follow in sub-section 3.4.

\section{Analysis, results, and discussion}

\subsection{Nonce words vs. neologisms}

In this sub-section, a quantitative analysis of the new blends in our database is carried out in order to distinguish nonce blends from blend neologisms, and thus investigate how blending contributes to the process of lexicalization [Blank 2001: 1605-1606; Brinton \& Traugott 2005: 41]. In general, both nonce formations and neologisms are considered innovations of a language. Specifically, a "nonce formation" is "a new complex word coined by a speaker/writer on the spur of the moment to cover some immediate need" [Bauer 1983: 45]. If it remains a single instance in the historical record, it is named "hapax legomenon" [Brinton \& Traugott 2005: 45]. By contrast, if it "comes to be accepted by part or all of the speech community", it becomes a "neologism" [Brinton \& Traugott 2005: 45]. Besides becoming relatively independent of context, a neologism is lexicalized, i.e. accepted into the lexicon of a language, and institutionalized, i.e. spread in the language of a community and established as the norm. 


\subsubsection{Nonce blends}

31 In our database, 25 examples of blending (10\%) are only attested in the OED, but unattested in the two corpora of English explored. Table 1 reports a sample (ten instances) of such nonce blends (all nouns except one adjective), followed by their source words, date/meaning, and a contextualized example taken from the OED quotes. The blends are arranged in chronological progression.

Table 1: Nonce blends in the OED

\begin{tabular}{|c|c|c|c|}
\hline Blend & Source words & Date/Meaning & Example \\
\hline cozzer (n.) & copper + rozzer & $\begin{array}{l}\text { [1950] a policeman; a } \\
\text { detective }\end{array}$ & $\begin{array}{l}\text { I don't know any cozzer who } \\
\text { would have tackled us, mob- } \\
\text { handed as we were. (OED, 1955) }\end{array}$ \\
\hline squoggy (adj.) & quaggy + soggy & [1950] wet and miry & $\begin{array}{l}\text { The ground's too squoggy to tell } \\
\text { whether they're male or female. } \\
\text { (OED, 1950) }\end{array}$ \\
\hline $\begin{array}{l}\text { saccharhinoceros } \\
\text { (n.) }\end{array}$ & $\begin{array}{l}\text { saccharine } \\
\text { rhinoceros }\end{array}$ & $\begin{array}{l}{[1951] \text { a lumbering }} \\
\text { person with an } \\
\text { excessively effusive } \\
\text { manner }\end{array}$ & $\begin{array}{l}\text { The saccharine of false purity } \\
\text { exuded from every pore of this } \\
\text { saccarhinoceros advocate of } \\
\text { virtue. (OED, 1951) }\end{array}$ \\
\hline utopiate (n.) & utopia + opiate & $\begin{array}{l}{[1964] \text { a hallucinogen }} \\
\text { which induces } \\
\text { fantasies or visions of } \\
\text { a perfect existence }\end{array}$ & $\begin{array}{l}\text { Their interest in psychedelics and } \\
\text { utopiates seems to have been } \\
\text { borrowed from the hippie } \\
\text { subculture. (OED, 2004) }\end{array}$ \\
\hline advertique (n.) & $\begin{array}{l}\text { advertisement }+ \\
\text { antique }\end{array}$ & $\begin{array}{l}\text { [1968] a piece of early } \\
\text { advertising material }\end{array}$ & $\begin{array}{l}\text { There will be 'advertiques' such as } \\
\text { classic Coca-Cola signs and beer- } \\
\text { logo items. (OED, 1994) }\end{array}$ \\
\hline computeracy (n.) & $\begin{array}{l}\text { computer } \\
\text { literacy } \\
\text { (cf. the adj. } \\
\text { computerate in } \\
\text { Table 2) }\end{array}$ & $\begin{array}{l}\text { [1969] knowledge of or } \\
\text { skill in using } \\
\text { computers }\end{array}$ & $\begin{array}{l}\text { Their 'computeracy' will provide } \\
\text { the basis for subsequent training, } \\
\text { retraining and the career changes } \\
\text { which will become increasingly } \\
\text { necessary. (OED, 1981) }\end{array}$ \\
\hline vestock (n.) & vest + stock & $\begin{array}{l}\text { [1975] a clerical stock } \\
\text { that extends to the } \\
\text { waist }\end{array}$ & $\begin{array}{l}\text { The vestock can be described as a } \\
\text { sort of black bib, with a hard } \\
\text { upstanding collar round at the } \\
\text { front. (OED, 1975) }\end{array}$ \\
\hline hoolivan (n.) & hooligan + van & $\begin{array}{l}\text { [1985] a type of police } \\
\text { van carrying } \\
\text { photographic and } \\
\text { video equipment for } \\
\text { observing crowd } \\
\text { behaviour }\end{array}$ & $\begin{array}{l}\text { The 'hoolivan' designed to detect } \\
\text { trouble-makers in football crowds, } \\
\text { was unveiled at the Chelsea-Luton } \\
\text { match at Stamford Bridge last } \\
\text { night. (OED, 1985) }\end{array}$ \\
\hline
\end{tabular}




\begin{tabular}{|l|l|l|l|}
\hline monergy (n.) & money + energy & $\begin{array}{l}\text { [1985] expenditure on } \\
\text { energy }\end{array}$ & $\begin{array}{l}\text { They ran a major awareness } \\
\text { campaign called Monergy in 1986, } \\
\text { which was Energy Efficiency Year. } \\
\text { (OED, 1992) }\end{array}$ \\
\hline gengineer (n.) & $\begin{array}{l}\text { genetic } \\
\text { engineer }\end{array}$ & $\begin{array}{l}{[1987] \text { a scientist who }} \\
\text { works in the field of } \\
\text { genetic engineering }\end{array}$ & $\begin{array}{l}\text { Biotechnologists, as the earliest } \\
\text { gengineers were called, had no } \\
\text { idea that their work would prove } \\
\text { so fruitful. (OED, 1987) }\end{array}$ \\
\hline
\end{tabular}

Although the blends in Table 1 are distributed between 1950 and 1987, it is not surprising that all of them are attested before 1990. This suggests that they have not survived more recent times. One of the blends (i.e. saccharhinoceros) is defined as a 'nonce-word' by the OED lexicographers themselves.

Table 2 instead reports a sample of ten blends for which either/both COCA or/and NOW display few occurrences, specified in the fourth column (raw/pmw frequency). 65 instances in our database (26.5\%) belong to this category.

Table 2: Nonce blends in COCA and NOW

\begin{tabular}{|c|c|c|c|c|}
\hline Blend & $\begin{array}{l}\text { Source } \\
\text { words }\end{array}$ & Date/Meaning & $\begin{array}{l}\text { Raw/Pmw } \\
\text { Frequency }\end{array}$ & Example \\
\hline $\begin{array}{l}\text { legalitarian } \\
\text { (adj.) }\end{array}$ & $\begin{array}{l}\text { legality } \\
\text { legal } \\
\text { egalitarian }\end{array}$ & $\begin{array}{l}\text { [1959] favouring } \\
\text { legislation as the } \\
\text { best means of } \\
\text { bringing about } \\
\text { greater social } \\
\text { equality }\end{array}$ & $\begin{array}{l}1 / 0.00 \\
(\mathrm{NOW})\end{array}$ & $\begin{array}{l}{[. . .] \text { they have a legalitarian }} \\
\text { standing before the law and } \\
\text { human conscience to pursue their } \\
\text { right to self-determination. } \\
(\text { NOW, 2017) }\end{array}$ \\
\hline $\begin{array}{l}\text { moondoggle } \\
\text { (n.) }\end{array}$ & $\begin{array}{l}\text { moon } \\
\text { boondoggle }\end{array}+$ & $\begin{array}{l}{[1962] \text { lunar }} \\
\text { exploration } \\
\text { regarded as a } \\
\text { frivolous waste of } \\
\text { money or time }\end{array} \mid$ & $\begin{array}{l}1 / 0.00 \\
(\operatorname{COCA})\end{array}$ & $\begin{array}{l}{[. . .] \text { communitarian theorist }} \\
\text { Amitai Etzioni was calling lunar } \\
\text { obsession a "moondoggle"... } \\
(\text { COCA, 2008) }\end{array}$ \\
\hline $\begin{array}{l}\text { acronymania } \\
\text { (n.) }\end{array}$ & $\begin{array}{l}\text { acronym } \\
\text { mania }\end{array}$ & $\begin{array}{ll}\text { [1968] fervent } & \text { or } \\
\text { excessive } & \\
\text { enthusiasm } & \text { for } \\
\text { the use } & \text { of } \\
\text { acronyms } & \text { or } \\
\text { initialisms } & \end{array}$ & $\begin{array}{l}1 / 0.00 \\
\text { (NOW) }\end{array}$ & $\begin{array}{l}\text { It also pioneered modern } \\
\text { acronymania: its divisions were } \\
\text { AMX (the DSP), PMX (publisher } \\
\text { exchange) and MMX (network } \\
\text { media exchange). (NOW, 2017) }\end{array}$ \\
\hline replicar (n.) & replica + car & $\begin{array}{l}\text { [1968] a full-sized, } \\
\text { functional replica } \\
\text { of a vintage or } \\
\text { classic car }\end{array}$ & $\begin{array}{l}4 / 0.00 \\
\text { (NOW) }\end{array}$ & $\begin{array}{l}\text { Still, he's had some experience in } \\
\text { the replicar realm with his } \\
\text { home-built Ferrari } 250 \text { GTO. } \\
\text { (NOW, 2013) }\end{array}$ \\
\hline
\end{tabular}




\begin{tabular}{|c|c|c|c|c|}
\hline $\begin{array}{l}\text { Newyorican } \\
\text { (n., adj.) }\end{array}$ & $\begin{array}{l}\text { New York + } \\
\text { Puerto Rican }\end{array}$ & $\begin{array}{l}{[1974] \text { a Puerto }} \\
\text { Rican native to or } \\
\text { inhabiting New } \\
\text { York City } \\
\begin{array}{ll}{[1978] \text { of or }} \\
\text { relating } & \text { to } \\
\text { Neoricans }\end{array}\end{array}$ & $\begin{array}{l}1 / 0.00 \\
\text { (NOW) }\end{array}$ & $\begin{array}{l}\text { Trio New York was formed in } \\
1994 \text { by Guillermo Colon (leader, } \\
\text { second voice and second guitar), } \\
\text { creating the sound of traditional } \\
\text { Puerto Rican jibaro music with a } \\
\text { Newyorican urban feel. (NOW, } \\
\text { 2010) }\end{array}$ \\
\hline $\begin{array}{l}\text { magalogue } \\
\text { (n.) }\end{array}$ & $\begin{array}{l}\text { magazine }+ \\
\text { catalogue }\end{array}$ & $\begin{array}{l}\text { [1978] a (usually } \\
\text { free) promotional } \\
\text { catalogue } \\
\text { designed to } \\
\text { resemble a high- } \\
\text { quality magazine }\end{array}$ & $\begin{array}{l}1 / 0.00 \\
(\text { COCA) } \\
4 / 0.00 \\
\text { (NOW) }\end{array}$ & $\begin{array}{l}\text { It's also known for the Christmas } \\
\text { Book, a magalogue filled with } \\
\text { extravagant his-and-her gifts, } \\
\text { such as airplanes and submarines. } \\
\text { (COCA, 2007) }\end{array}$ \\
\hline $\begin{array}{l}\text { chemigation } \\
\text { (n.) }\end{array}$ & $\begin{array}{l}\text { chemical }+ \\
\text { irrigation }\end{array}$ & $\begin{array}{l}\text { [1981] the } \\
\text { practice of } \\
\text { applying } \\
\text { chemicals to } \\
\text { crops by means of } \\
\text { irrigation water }\end{array}$ & $\begin{array}{l}3 / 0.00 \\
\text { (NOW) }\end{array}$ & $\begin{array}{l}\text { Herbicides can also be delivered } \\
\text { through irrigation systems } \\
\text { (chemigation). (NOW, 2017) }\end{array}$ \\
\hline $\begin{array}{l}\text { computerate } \\
\text { (adj.) }\end{array}$ & $\begin{array}{l}\text { computer }+ \\
\text { literate }\end{array}$ & $\begin{array}{l}\text { [1981] familiar } \\
\text { with or skilled in } \\
\text { the use of } \\
\text { computers }\end{array}$ & $\begin{array}{l}1 / 0.00 \\
\text { (NOW) }\end{array}$ & $\begin{array}{l}\text { Najib revealed that computerate } \\
\text { corporate ownership was merely } \\
10 \% \text { and yet to achieve a target of } \\
\text { at least } 30 \% \text {. (NOW, 2013) }\end{array}$ \\
\hline Squarial (n.) & $\begin{array}{l}\text { square } \\
\text { aerial }\end{array}$ & $\begin{array}{l}{[1988] \text { a }} \\
\text { proprietary name } \\
\text { for a type of } \\
\text { diamond-shaped } \\
\text { dish aerial for } \\
\text { receiving satellite } \\
\text { television } \\
\text { broadcasts }\end{array}$ & $\begin{array}{l}4 / 0.00 \\
\text { (NOW) }\end{array}$ & $\begin{array}{l}\text { History of BSkyB: when the ' } \\
\text { squarial' met the dish British Sky } \\
\text { Broadcasting (BSkyB) was } \\
\text { created... (NOW, 2011) }\end{array}$ \\
\hline $\begin{array}{l}\text { webliography } \\
\text { (n.) }\end{array}$ & $\begin{array}{l}\text { web + } \\
\text { bibliography }\end{array}$ & $\begin{array}{l}\text { [1995] a list of } \\
\text { electronic works } \\
\text { relating to a } \\
\text { particular topic }\end{array}$ & $\begin{array}{l}3 / 0.01 \\
(\operatorname{COCA})\end{array}$ & $\begin{array}{l}\text { Volume } 2 \text { contains a lengthy } \\
\text { bibliography and webliography } \\
\text { of additional resources. (COCA, } \\
\text { 2012) }\end{array}$ \\
\hline
\end{tabular}

34 The blends reported in Table 2 are first attested in the 1950s-1990s in the OED, but they also occur more recently in COCA and NOW. However, these blends have been considered nonce blends because their normalized frequency is no higher than 0.00 (max. 1 occ. in COCA or 1-4 occ. in NOW). One of them (i.e. Squarial) has been labelled 'temporary' in the OED.

Other blends in our database display the same low frequency in corpora: e.g., the adjective sexploitative [1973] $(\leftarrow$ sex + exploitative $)$ occurs only once in NOW, but the related noun sexploitation 'sexual exploitation' already existed in 1924 and has a current 
raw frequency of 185 occ. (0.03 pmw) in NOW (see also the noun sexploit [1960] 'sexual exploit', $3 / 0.00$ occ. in NOW).

Similarly, the adjective televangelical [1976] $(\leftarrow$ television + evangelical) occurs only once in COCA, but the occurrences of the nouns televangelism [1958] (30/0.05 in COCA, 78/0.01 in NOW) and televangelist [1973] (167/0.30 in COCA, 1,494/0.27 in NOW) are undeniably higher. The existence of word families of blends including derived nouns and adjectives is also symptomatic of the productivity of the process and of the stability of the pattern.

\subsubsection{Blend neologisms}

Blend neologisms are more difficult to ascertain. In order to be considered a lexicalized word, the new blend should display high raw/normalized frequency in corpora. Table 3 only reports the blends whose normalized frequency is higher than $0.10 \mathrm{pmw}$ in at least one (but preferentially both) of the corpora checked (overall 42 instances/17\% in our database). ${ }^{2}$ These are considered to be the ideal candidates for lexicalization/ institutionalization in English.

Table 3: Blend neologisms in COCA and NOW

\begin{tabular}{|c|c|c|c|c|}
\hline Blend & $\begin{array}{l}\text { Source } \\
\text { words }\end{array}$ & Date/Meaning & $\begin{array}{l}\text { Raw/Pmw } \\
\text { Frequency }\end{array}$ & Example \\
\hline Muppet (n.) & $\begin{array}{l}\text { marionette }+ \\
\text { puppet }\end{array}$ & $\begin{array}{lr}{[1955] \text { any }} & \text { of a } \\
\text { number } & \text { of } \\
\text { humorously } & \\
\text { grotesque glove } \\
\text { puppets } \\
\begin{array}{lr}\text { marionettes } \\
\text { developed }\end{array} \\
\text { Henson } & \text { by } \\
\end{array}$ & $\begin{array}{l}214 / 0.38 \\
(\text { COCA }) \\
2,833 / 0.52 \\
\text { (NOW) }\end{array}$ & 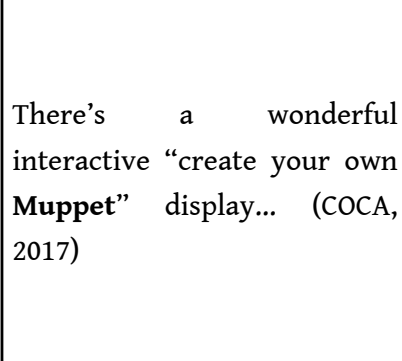 \\
\hline $\begin{array}{l}\text { dexamethasone } \\
\text { (n.) }\end{array}$ & $\begin{array}{l}\text { deca- 'ten' + } \\
\text { hexadecadrol } \\
+ \text { methyl + } \\
\text { cortisone }\end{array}$ & $\begin{array}{l}{[1958] \text { a synthetic }} \\
\text { steroid, } \\
\text { C22H29FO5, which } \\
\text { resembles } \\
\text { cortisone in its } \\
\text { effects and is used } \\
\text { as an anti- } \\
\text { inflammatory } \\
\text { agent }\end{array}$ & $\begin{array}{l}152 / 0.27 \\
(\text { COCA) } \\
852 / 0.15 \\
\text { (NOW) }\end{array}$ & $\begin{array}{l}\text { Global effects of a synthetic } \\
\text { GR ligand Dexamethasone } \\
\text { (Dex) have been studied in } \\
\text { cells treated with Dex prior to } \\
\text { or together with an } \\
\text { inflammatory stimulus. } \\
(\text { COCA, 2017) }\end{array}$ \\
\hline cyborg (n.) & $\begin{array}{l}\text { cybernetic }+ \\
\text { organism }\end{array}$ & $\begin{array}{lr}{[1960]} & \text { a } \\
\text { whose } & \text { physical } \\
\text { tolerances } & \text { or } \\
\text { capabilities } & \text { are } \\
\text { extended beyond } \\
\text { normal human } \\
\text { limitations by a } \\
\text { machine }\end{array}$ & $\begin{array}{l}347 / 0.61 \\
(\text { COCA) } \\
5,972 / 1.09 \\
\text { (NOW) }\end{array}$ & $\begin{array}{l}\text { It was a prototype, cyborg, } \\
\text { self-repairing, able to train its } \\
\text { own caretakers. (COCA, 2017) }\end{array}$ \\
\hline
\end{tabular}




\begin{tabular}{|c|c|c|c|c|}
\hline stagflation (n.) & $\begin{array}{l}\text { stagnation + } \\
\text { inflation }\end{array}$ & $\begin{array}{l}\text { [1965] a state of } \\
\text { the economy in } \\
\text { which stagnant } \\
\text { demand is } \\
\text { accompanied by } \\
\text { severe inflation }\end{array}$ & $\begin{array}{l}115 / 0.20 \\
(\mathrm{COCA}) \\
1,095 / 0.20 \\
(\mathrm{NOW})\end{array}$ & $\begin{array}{l}\text { The CED's influence and } \\
\text { membership declined in the " } \\
\text { stagflation" era of } 1973 \text { to } \\
1980 \text {, when the Business } \\
\text { Roundtable supplanted it as } \\
\text { the leading spokesman for big } \\
\text { business. (COCA, 2017) }\end{array}$ \\
\hline $\begin{array}{l}\text { Reaganomics } \\
\text { (n.) }\end{array}$ & $\begin{array}{l}\text { (Ronald) } \\
\text { Reagan }+ \\
\text { economics }\end{array}$ & $\mid \begin{array}{lr}{[1970]} & \text { the } \\
\text { economic } & \text { policies } \\
\text { of Reagan }\end{array}$ & $\begin{array}{l}164 / 0.29 \\
(\text { COCA }) \\
322 / 0.06 \\
\text { (NOW) }\end{array}$ & $\begin{array}{l}\text { The Republican base was } \\
\text { always wary of George H.W. } \\
\text { Bush. In 1980, he called } \\
\text { Reaganomics voodoo } \\
\text { economics. (COCA, 2015) }\end{array}$ \\
\hline $\begin{array}{l}\text { televangelist } \\
\text { (n.) }\end{array}$ & $\begin{array}{l}\text { television }+ \\
\text { evangelist }\end{array}$ & $\begin{array}{l}{[1973] \text { an }} \\
\text { evangelical } \\
\text { preacher who } \\
\text { appears regularly } \\
\text { on television to } \\
\text { preach and appeal } \\
\text { for funds }\end{array}$ & $\begin{array}{l}167 / 0.30 \\
(\text { COCA }) \\
1,494 / 0.27 \\
(\text { NOW })\end{array}$ & $\begin{array}{l}\text { We were saying Mark Burns is } \\
\text { the pastor, the televangelist } \\
\text { with the Now Network, } \\
\text { because we jumped the gun. } \\
\text { (COCA, 2016) }\end{array}$ \\
\hline $\begin{array}{l}\text { brainiac (n., } \\
\text { adj.) }\end{array}$ & $\begin{array}{l}\text { brain } \\
\text { maniac }\end{array}$ & \begin{tabular}{|lr}
{$[1975] \quad$ a } & very \\
intelligent & person; \\
an expert & \\
{$[1976]$} & very \\
intelligent & or \\
clever &
\end{tabular} & $\begin{array}{l}60 / 0.11 \\
(\mathrm{COCA}) \\
736 / 0.13 \\
(\mathrm{NOW})\end{array}$ & $\begin{array}{l}\text { She is a brainiac, wicked } \\
\text { smart, or as the Scots would } \\
\text { say, wicked smart. (COCA, } \\
2014 \text { ) }\end{array}$ \\
\hline Bollywood (n.) & $\begin{array}{l}\text { Bombay + } \\
\text { Hollywood }\end{array}$ & $\begin{array}{l}\text { [1976] the Indian } \\
\text { film industry, } \\
\text { based in Mumbai } \\
\text { (formerly } \\
\text { Bombay) }\end{array}$ & $\begin{array}{l}292 / 0.52 \\
(\text { COCA }) \\
122,908 / 22.35 \\
(\text { NOW })\end{array}$ & $\begin{array}{l}\text { She knew Sweetie had pulled } \\
\text { every string he could to get } \\
\text { her the audition with } \\
\text { Bollywood's top dance } \\
\text { troupe. (COCA, 2017) }\end{array}$ \\
\hline bromance (n.) & $\begin{array}{l}\text { bro } \\
\text { romance }\end{array}$ & $\begin{array}{l}{[2001] \text { intimate }} \\
\text { and affectionate } \\
\text { friendship } \\
\text { between men }\end{array}$ & $\begin{array}{l}80 / 0.14 \\
(\text { COCA }) \\
3,355 / 0.61 \\
\text { (NOW) }\end{array}$ & $\begin{array}{l}\text { Yes, the least - the least } \\
\text { convincing bromance of all } \\
\text { time is Donald Trump and } \\
\text { Mitch McConnell. (COCA, } \\
\text { 2017) }\end{array}$ \\
\hline burkini (n.) & $\begin{array}{l}\text { burka } \\
\text { bikini }\end{array}$ & $\begin{array}{l}\text { [2002] a type of } \\
\text { swimsuit for } \\
\text { women which } \\
\text { covers the head } \\
\text { and body }\end{array}$ & $\begin{array}{l}21 / 0.04 \\
(\mathrm{COCA}) \\
2,259 / 0.41 \\
\text { (NOW) }\end{array}$ & $\begin{array}{l}\text { She was also the first woman } \\
\text { to wear a burkini during the } \\
\text { swimsuit portion of the event. } \\
\text { (COCA, 2017) }\end{array}$ \\
\hline
\end{tabular}

The blends reported in Table 3 are distributed from 1955 to 2002. Their high frequency in corpora suggests a status as 'neologisms'. The specialization of some of them - e.g., dexamethasone is used in Pharmacology, cyborg belongs to Cybernetics and thence to science fiction, stagflation to the field of Economics, Reaganomics to Politics - guarantees 
that they have been accepted at least within their respective specialized communities of experts. The acceptability and spread of the other blends may be instead linked to their dissemination through the media: e.g., Muppet and televangelist are heard in television, Bollywood is linked to the cinema industry, and burkini has recently heated religious discussions in the news.

A more systematic examination of the registers, contexts, and functions of new blends in English can help us corroborate the impact of blending on the innovation and lexicalization processes.

\subsection{Registers, contexts, and functions of new blends}

\subsubsection{Registers}

In our database, the prevailing registers of blend lexemes include slang (i.e. language of a highly colloquial type, considered as below the level of standard educated speech) (7.3\%) and colloquial (i.e. informal) language (7\%), on the one hand, and specialized language and jargon (24.5\%) on the other.

- Slang: slang blends are often employed by speakers who intend to catch the reader/hearer's attention with their colourful language, to be humorous, jocular, or otherwise by those who aim at mocking, offending others by using a sarcastic or derisive tone. Novel instances include: chugger / chugging $(\leftarrow$ charity + mugger / mugging), cozzer $(\leftarrow$ copper + rozzer $)$, feminazi $(\leftarrow$ feminist + Nazi $)$, gaydar $(\leftarrow$ gay + acronym radar $)$, kideo $(\leftarrow$ kid + video $)$, ragazine $(\leftarrow$ rag + magazine), skeeze $(\leftarrow$ skank + sleaze $)$, skitch $(\leftarrow$ ski / skate + hitch $)$, snarfle $(\leftarrow$ snarf + snaffle I snuffle), and ultraviolation $(\leftarrow$ ultraviolet + violation). Some slang blends display a derogatory character (e.g. himbo 'an attractive but unintelligent young man' $\leftarrow$ him + bimbo, brainiac 'a depreciative word for a very intelligent person' $\leftarrow$ brain + maniac), or are even taboo words (fugly 'very ugly' $\leftarrow$ fucking + ugly, Masshole 'a term of contempt for a native of the state of Massachusetts' $\leftarrow$ Massachusetts + asshole). Others are mere innovative original forms used by the young (e.g. fantabulous $\leftarrow$ fantastic + fabulous), or originated in the context of hip-hop music (e.g. crunk 'exciting or fun' $\leftarrow$ crazy + drunk).

- Colloquial language: colloquial blends have a familiar flavour, which is typical of informal registers. They include: blaxploitation $(\leftarrow$ black + exploitation $)$, bromance $(\leftarrow$ bro + romance), buppie $(\leftarrow$ black + acronym yuppie $)$, Cassingle $(\leftarrow$ cassette + single $)$, gayby boom $(\leftarrow$ gay + baby boom), Mockney $(\leftarrow$ mock + Cockney), sexploit / sexploitative $(\leftarrow$ sex + exploit / exploitative), Trustafarian $(\leftarrow$ trust fund + Rastafarian), and wuss $(\leftarrow$ wimp + puss). Familiar blends, such as the form of address glam-ma $(\leftarrow$ glamour(ous) + grandma), add to other humorous nicknames, such as Socceroos ( $\leftarrow$ soccer + kangaroo) for 'the Australian national soccer team', or Taffia 'any supposed network of prominent or influential Welsh people', from Taffy 'familiar nickname for a Welshman' and mafia.

- Specialized language: specialized or domain-specific blends belong to a variety of different fields and sub-fields:

- Some belong to the areas of Economics (slumpflation $\leftarrow$ slump + inflation), Business (adhocracy / adhocratic $\leftarrow$ ad hoc + bureaucracy / bureaucratic, flexecutive $\leftarrow$ flexible + executive, freemium $\leftarrow$ free + premium, glocal $\leftarrow$ global + local), and Law (legalitarian $\leftarrow$ legality / legal + egalitarian).

- Several others are used in Politics (Clintonomics $\leftarrow$ Clinton + economics, commentariat $\leftarrow$ commentary + proletariat, dissensus $\leftarrow$ dissent + consensus, hacktivism / hacktivist $\leftarrow$ hack + activism / activist, militician $\leftarrow$ military + politician, politicide $\leftarrow$ political + homicide, 
preferendum $\leftarrow$ preference + referendum, selectorate $\leftarrow$ selector + electorate, slacktivism $/$ slacktivist $\leftarrow$ slack + activism / activist, veepstakes $\leftarrow$ veep + sweepstakes, priviligentsia $\leftarrow$ privilege + intelligentsia)

- The scientific domain also provides a range of blends which pertain to Mathematics (diffeomorphism / diffeomorphic $\leftarrow$ differentiable + homoeomorphism / homoeomorphic, flexagon $\leftarrow$ flex + hexagon), Biology (algeny $\leftarrow$ alchemy + gene, cybrid $\leftarrow$ cytoplasmic + hybrid), Chemistry (dielectrophoresis $\leftarrow$ dielectric + electrophoresis), Biochemistry (ubiquinone $\leftarrow$ ubiquitous + quinone), Pharmacology (artemisinin $\leftarrow$ artemisia + quinine, cephaloridine $\leftarrow$ cephalosporin + pyridine, nitrofurantoin $\leftarrow$ nitrofuran + hydantoin), Surgery (dermabrasion $\leftarrow$

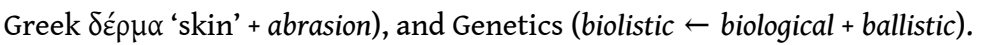

- The technological arena ranges from Computing (Centronics $\leftarrow$ centre / central + electronics, Internaut $\leftarrow$ Internet + astronaut, knowbot $\leftarrow$ know + robot, netiquette $\leftarrow$ net + etiquette, netizen $\leftarrow$ net + citizen, Quotron $\leftarrow$ quotation + electron, Usenet $\leftarrow$ use + network) to Electronics (molectronics $\leftarrow$ molecular + electronics, rectenna $\leftarrow$ rectifying + antenna), from Cybernetics (cyborg) to Aeronautics (taileron $\leftarrow$ tail + aileron).

- Domain-specific blends belong to Film/Television/Broadcasting (animatic $\leftarrow$ animated + schematic, Britcom $\leftarrow$ British + comedy, Japanimation $\leftarrow$ Japan + animation, synthespian $\leftarrow$ synthetic + Thespian), Science Fiction (gengineering / gengineer $\leftarrow$ genetic + engineering / engineer, plasteel $\leftarrow$ plastic + steel), Telecommunications (teletex $\leftarrow$ telex + text), Architecture (Populuxe $\leftarrow$ popularity + Fr. luxe), and Nautical (Panamax 'a class of cargo ship' $\leftarrow$ Panama (Canal) + max).

- Minor domains include: Agriculture (chemigation $\leftarrow$ chemical + irrigation, fertigation $\leftarrow$ fertilizer + irrigation), Palaeography (expunctuation $\leftarrow$ expunction + punctuation), and Geology (volcaniclastic $\leftarrow$ volcanic + clastic) .

41 Specialized contexts especially favour the creation of blends whose form mirrors their meaning. The iconicity of blends is especially evident in pharmacology, where names of substances (artemisinin, nitrofurantoin) refer to mixtures, combinations, fusions, but also in television and broadcasting, where an informercial ( $\leftarrow$ information + commercial) is 'an advertisement which promotes a product, service, etc., in an informative style', or in publishing, where a magalogue is 'a promotional catalogue designed to resemble a highquality magazine'.

\subsubsection{Contexts and functions/effects}

Blends can be found in heterogeneous contexts and used in different circumstances, depending on their formal or informal nature, on the effects that they are meant to produce, and on the goals that speakers intend to achieve through them.

In magazine and news articles, for example, creative blends are used to catch readers' attention and encourage them in reading the whole news items. Examples (1) and (2) are both extracts from magazines:

(1) [...] she sent a sext 'sex + text' from the presidential Twitter account. (COCA, 2016)

(2) Ariela Barer will play Gert, "a purple-haired, bespectacled, contemporary riot grrrl" 'grrr + girl' with a strong sense of social justice. (COCA, 2017)

where sext refers to 'a sexually suggestive message sent electronically' and grrrl designates 'a young woman perceived as strong and aggressive'. Readers will be particularly attracted by the originality of these expressions, and their attention will be 
focused on the fact that the text is on sexually-related topics (sext), or that the character of the grrrl - with the interjection grrr jocularly alluding, by alliteration, to her name Gert - expresses feminine independence, fierceness, and liveliness.

Informal contexts favour blend creation with the aim of creating intimacy within a group, such as surfers:

(3) [...] they were interested and in 1965 organized a "surfari" 'surf + safari' to the west of Ireland. (NOW, 2010) Presidents' (Ronald Reagan and Bill Clinton) economic policies, while in (6) Trumpflation is a novel term created after slumpflation [1974] referring to 'a state of economic depression'. In specialized domains, the creation of new blends appears to be more regular: e.g., the target word Clintonomics [1992] is analogically coined after the model Reaganomics [1970], and the nonce form Trumpflation is modelled on earlier stagflation [1965] and slumpflation [1974], the latter anaphorically following the target in (6) (Mattiello 2017; more on analogy in § 3.3.).

51 Technological settings, such as computing and the Internet, can also accommodate novel blends, as in:

(7) The unit introduces students to the structure of blogs, the concept of a world-wide audience, and general netiquette 'net + etiquette' policies. (COCA, 2012)

(8) Kahn [...] is the co-inventor of Knowbot 'know + robot' programmes mobile software agents in the network environment. (NOW, 2015) denotes 'a type of automated program or (Internet) software' (cf. infobot). Overall, in specialized environments, new blends have the function of creating cohesion among experts, as well as designating specific referents by means of efficient terminology. 

where new blends give names to language varieties, such as African-American English (Ebonics), or jocular accents imitating London Cockney (mockney):

(9) He had no idea how to speak Spanish, didn't speak Ebonics 'ebony + phonics', either. (COCA, 2017)

(10) These scenes, and the mockney 'mock + Cockney' chants of "Who are ya?", were widely derided as the work of wannabes posturing for the day. (NOW, 2018)

Blends are also used to refer to new types of music, such as soca, a variety of calypso (cf. rapso $\leftarrow$ rap + calypso), or hip-hopera, combining the two genres:

(11) Add in calypso and soca 'soul + calypso' music, and you have a recipe for success week after week... and year after year; the event dates to 2000 . (COCA, 2011)

(12) Years ago, someone (was it the Fat Boys?) attempted "hip-hopera" 'hiphop + opera'. (COCA, 1999)

Many novel forms of entertainment are given blend names. Octopush, for instance, is 'a game similar to ice hockey in which a weight is pushed along on the bottom of a swimming pool by two rival teams of divers':

(13) He needed a sport that could be played in a pool; his idea, a game called "Octopush," 'octopus + push' began to spread. (NOW, 2013)

and glamping is a new form of "camping that involves accommodation and facilities more luxurious than those associated with traditional camping':

(14) Let's talk about glamping 'glamorous + camping'. I know Beyonce and Jay-Z do it. (COCA, 2016)

One can also appreciate the 'new form of animated films produced using the graphics engine from a video game' (machinima):

(15) [...] their storyboarding, recorded video in Second Life in a machinima 'machine + cinema' format, and constructed three-dimensional "emotional spaces" called Storyworlds. (COCA, 2009)

or enjoy 'episodes of a comedy series, which are made available online' (webisodes):

(16) Nimbus became one of the early experimenters with the short online film, or "webisode" 'web + episode'. (COCA, 2012)

60 Tourism 'in which travellers spend time doing voluntary work' is now called voluntourism:

(17) Still, so-called voluntourism 'volunteer + tourism' is a tricky business. (COCA, 2013) and 'a person who follows a primarily but not strictly vegetarian diet' is a flexitarian:

(18) If these facts have persuaded you to eat less meat, and to choose pastured or grass-fed when you do, then you're on the brink of becoming a

flexitarian 'flexible + vegetarian'. (COCA, 2014) 

restaurants' is a freegan:

(19) Surplus vegetables collected by the freegan 'free + vegan' group were redistributed to soup kitchens and community fridges. (NOW, 2018)

63 Fashion is another setting where new blend words may be coined, especially to find names for garments which have a hybrid appearance, such as 'a two-piece swimsuit for women, consisting of a bikini bottom and a top part in the style of a tank top' (tankini):

(20) A bold bronze tankini 'tank top + bikini' inspires body confidence and attitude. (COCA, 2010)

64 or 'a pair of shorts having a flap across the front to give the appearance of a skirt' (skort):

(21) I'm not a fashionista, as my current attire showed: denim skort 'skirt + short(s)', sleeveless white shirt, casual sandals. (COCA, 2013)

65 Finally, hybrid animals, cross-breeds from two species, are given iconic names, such as zonkey 'the offspring of a zebra and a donkey' (cf. zedonk, zebrule), beefalo 'a cross-bred livestock animal that is three-eighths bison and five-eighths domestic cow' (cf. catalo), or labradoodle 'a dog cross-bred from a Labrador retriever and a poodle':

(22) The two pen pals producing as zonkey 'zebra + donkey', a cross between a zebra and a donkey... (COCA, 2013)

(23) The Fort served perfectly medium-rare beefalo 'beef + buffalo'. (COCA, 2004)

(24) Only Sylvia's not a woman - she's a dog; a labradoodle 'Labrador + poodle', to be precise. (COCA, 2017):

The function of defining a new category of people (e.g. screenager or kidult) is less common, and even rarer by using a blend adjective (computerate):

(25) A screenager's 'screen + teenager' constant companion is the television screen, which can be used to watch the news or a cartoon... (COCA, 1997)

(26) Many kidult 'kid + adult' use their savings to buy and display toys and figurines that used to be their childhood fascination. (NOW, 2018)

(27) Najib revealed that computerate 'computer + literate' corporate ownership was merely $10 \%$ and yet to achieve a target of at least $30 \%$. NOW, 2013)

New blend names are also given to towers (Skylon) and cities (Queuetopia, humorously alluding to Great Britain's queuing habits):

(28) Gazing out over the falls from the Skylon 'sky + pylon' Tower, travellers can ride the elevator to the observation deck and enjoy a view over American Falls, Bridal Veil Falls, and Horseshoe Falls. (NOW, 2018)

(29) In Queuetopia 'queue + utopia' - Britain - people are practically crazy for queuing. (NOW, 2017)

In product and brand names, we find general instances, such as: 
(30) I got a koozie 'cool + cosy', a beer koozie, that says storm on it. (COCA, 2012)

(31) Amazon is reportedly developing a freemium 'free + premium' version of Prime Video. (COCA, 2017)

But we also find trademarks of, especially, foods and drinks:

(32) Their Meritage ${ }^{\mathrm{TM}}$ 'merit + heritage' Espresso is the inspiration for Rashelle's creamy mousse. (COCA, 2011)

(33) [...] a Pinot Noir with a Hermitage vine to develop the Pinotage ${ }^{\text {TM }}$ 'Pinot + hermitage', South Africa's signature grape. (COCA, 2012)

(34) Add gin or vodka, dash of Tabasco, Worcestershire, Clamato ${ }^{\mathrm{TM}}$ 'clam + tomato' juice and horseradish (optional). (NOW, 2018)

or other types of product:

(35) The Thinsulate ${ }^{\mathrm{TM}}$ 'thin + insulate' pants could not be doing much good against the cold, because they left very little to the imagination. (COCA, 2016) (36) "Psychedelicatessen ${ }^{\mathrm{TM}}$ " 'psychedelic + delicatessen' - Advance tickets (\$ 12) for the Jan. 12 rave dance at International Ballroom are available at Ticketmaster. (COCA, 1992)

(37) He wrote his first three books on an IBM Selectric ${ }^{\mathrm{TM}}$ 'select + electric' typewriter, which was more his style. (COCA, 2010)

71 Thus confirming the predominant role of blending for naming/labelling purposes, as anticipated in $\S 2$.

\subsection{Blends and analogy}

From the formal viewpoint, some blends can be accommodated within the model of analogy in word-formation elaborated in Mattiello [2017]. In particular, this subsection is devoted to the distinction between blends that are analogical to a precise model word - sharing formal (morphotactic) and semantic similarity with it - and blends that are instead created after a series of words which act as schema model. The former type is obtained by surface analogy (after Motsch's [1981:101] "Oberflächenanalogie") and the latter is created via a schema (cf. Köpcke [1993] for "schema" in inflectional morphology). A schema does not have the same level of abstraction as word-formation rules, but consists of two or more words which function as concrete prototypes for novel formations.

\subsubsection{Surface analogy}

Bauer [1983: 96] defines an analogical formation as "a new formation clearly modelled on one existing lexeme". Compounds such as whitelist, coined after its antonym blacklist, well illustrate this phenomenon. However, like compounds, new blends can also be created on a precise model. Consider, for instance, the blends smaze $(\leftarrow$ smoke + haze) and $\operatorname{vog}(\leftarrow$ volcanic $+f \circ g)$, which have been coined after the exact model word smog $(\leftarrow$ smoke + fog), lexicalized in English. The similarity relation between model (smog) and targets (smaze, vog) can be analyzed as a paradigmatic substitution in the equations:

$$
\text { smoke }{ }^{\wedge} \text { fog }: \text { smog }=\text { smoke }^{\wedge} \text { haze }: X(X=\text { smaze })
$$


smoke $^{\wedge}$ fog $:$ smog $=$ volcanic ${ }^{\wedge}$ fog $: X(X=$ vog $)$ blend smaze, while the replacement of smoke with volcanic gives vog. Both new blends
share with their model 1) a formal resemblance, merging a word beginning with a word
end, 2) a phonological resemblance (onset sm- /sm/ in the first blend and rhyme -og /
$\mathrm{pg} /$ in the second blend), and a semantic similarity, in that, like smog, which iconically
refers to 'fog intensified by smoke', smaze is 'a mixture of smoke and haze' and vog is 'fog
containing volcanic dust'. However, while smaze is, like smog, a coordinate blend
combining two nouns, vog is a headed blend, with an adjective (volcanic) modifying the
head fog. From the diachronic viewpoint, the targets smaze [1953] and vog [1969] follow
the model smog [1905].

Other novel blends in our database which are coined by surface analogy include:

- blaxploitation [1972] 'the exploitation of black people' $\leftarrow$ black + exploitation, after sexploitation [1924] 'sexual exploitation' $\leftarrow$ sex + exploitation;

- Britcom [1977] 'a comedy film produced in the United Kingdom' $\leftarrow$ sitcom [1964] 'situation comedy', here the model is a clipped compound (cf. the analysis of Britcom as a blend from British and sitcom; see also romcom [1971] 'romantic comedy');

- Motopia [1959] 'an urban environment designed to meet the needs of a pedestrian society by strict limitation of the use of the motor car' $\leftarrow$ motor + utopia, after Subtopia [1955] 'Suburbia regarded as an undesirable or unattractive place to live' $\leftarrow$ suburb + utopia;

- politicide [1967] 'the killing of a particular group because of its political beliefs' $\leftarrow$ political + homicide, after genocide [1944] 'the deliberate and systematic extermination of an ethnic or national group' $\leftarrow$ genus + homicide;

- ragazine [1987] 'a magazine of inferior quality' $\leftarrow$ colloquial rag + magazine, after fanzine [1949] 'a magazine for fans' $\leftarrow$ fanatic + magazine;

- slumpflation [1974] $\leftarrow$ slump + inflation, after stagflation $[1965] \leftarrow$ stagnation + inflation (see § 3.2.2.);

- threequel [1983] 'the third of a sequence of films' $\leftarrow$ three + sequel, after prequel [1958] 'a book, film, etc., narrating events which precede those of an already existing work' $\leftarrow$ pre- + sequel (with a substitution of the prefix pre- with the rhyming numeral three).

These examples show how analogy increases regularity and helps predictability in blend formation. The type of blend obtained after a schema model is even more regular and productive, in that it creates novel splinters.

\subsubsection{Analogy via schema, series, and splinters}

While Bauer [1983: 96] claims that analogy does not give rise to productive series and Plag [1999:210] argues that "analogical formations should be distinguished from instantiations of productive word formation rules", analogy via schema can originate series, i.e. formations which share the same process. In particular, analogy can produce novel "splinters", defined by Bauer et al. [2013:525] as "non-morphemic portions of a word that have been split off and used in the formation of new words with a specific new meaning". Splinters can be obtained by mere abbreviation of a word, as in -ware ( software), used in the creation of freeware, shareware 'software which is available free of charge', and vapourware 'piece of software which, despite being publicized or marketed, does not exist', in which the meaning conveyed is that of the full form 'software'. Another way to obtain splinters is by secretion, i.e. reinterpretation of a word part. For 
instance, the splinter -gram $(\leftarrow$ telegram) has extended from the meaning 'a message sent by telegraph' to 'a message delivered by a representative of a commercial greetings company, esp. one outrageously dressed to amuse or embarrass the recipient', as in kissogram 'a greetings message delivered with a kiss' or strippergram 'message delivered by a performer of strip-tease'. Productive splinters in our database include:

- -bot $(\leftarrow$ robot) 'automated program which searches out information', as in infobot [1986] 'any of various automated systems for obtaining information', knowbot [1988] 'program designed to search and retrieve information from the Internet', cancelbot [1993] 'a program that searches for and deletes specified postings from Internet newsgroups', and the nonce words searchbot, googlebot, etc. found in the OED.

- -ercise ( $\leftarrow$ exercise) 'physical or non-physical but strenuous activity', as in sexercise [1942] 'sexual activity regarded as exercise', dancercise [1967] 'dancing performed as an exercise', followed by jazzercise [1976] 'a programme of physical exercises designed to be carried out in a class to the accompaniment of jazz music' $\leftarrow$ jazz + -ercise, and boxercise [1985] 'a form of aerobic fitness routine incorporating exercises from boxing training' $\leftarrow$ box +- -ercise.

- -kini ( $\leftarrow$ the atoll of Bikini, reanalysed as having a prefix bi-) 'type of swimsuit or beach garment for women', as in monokini [1964] 'a one-piece beach garment or swimming costume worn usually by women', trikini [1967] 'any of various designs of ladies' swimsuit which consist of three main areas of fabric', and analogical tankini [1985] $\leftarrow$ tank top + -kini (see § 3.2.2.) and burkini [2002] 'a type of swimsuit for women which covers the head and body' $\leftarrow$ burka +-kini.

- -lish ( $\leftarrow$ English) 'variety of English displaying features of other languages', as in Spanglish [1933] 'a mixture of Spanish and English', originating Chinglish [1957] 'a mixture of Chinese and English' $\leftarrow$ Chinese + -lish, Japlish [1960] 'English language spoken in an unidiomatic way by a Japanese speaker' $\leftarrow$ Japanese + -lish, Hinglish [1967] 'a mixture of Hindi and English' $\leftarrow$ Hindi + -lish, Singlish [1984] 'an informal variety of English spoken in Sri Lanka, incorporating elements of Sinhala' $\leftarrow$ Sinhalese + -lish, or Singlish [1984] 'an informal variety of English spoken in Singapore' $\leftarrow$ Singaporean + -lish.

--(o)nomics ( $\leftarrow$ economics) 'the economic policies of a President or head of state', as in Nixonomics [1969] 'the economic policies of Richard Nixon', and analogical Reaganomics [1970] $\leftarrow$ (Ronald) Reagan + -nomics, Clintonomics [1992] $\leftarrow$ Clinton + -nomics, Rogernomics $\leftarrow$ Roger (Owen Douglas, New Zealand Minister of Finance) + -nomics. This splinter is often blended with words that end in $n$ (Nixon, Reagan, Clinton), thus creating overlap blends.

- -tainment ( $\leftarrow$ entertainment) 'genre of broadcasting in which entertainment is combined with another genre', as in docutainment [1978] 'a film which includes documentary materials, and seeks both to inform and to entertain', infotainment [1980] 'broadcast material which seeks to inform and entertain simultaneously', edutainment [1983] 'informative entertainment', and analogical eatertainment [1992] 'an experience which combines eating with entertainment' $\leftarrow$ eat + -(er)tainment, irritainment [1993] 'broadcast material which is irritating yet still entertaining' $\leftarrow$ irritating + -tainment, and shoppertainment [1993] 'the provision of entertainment within a shopping centre' $\leftarrow$ shopper +-tainment.

- -tarian ( $\leftarrow$ vegetarian) 'someone with a diet restriction', as in dietarian [1880] 'one who lives in accordance with prescribed rules for diet', fruitarian [1893] 'one who lives on fruit', nutarian [1909] 'vegetarian whose diet is based on nut products', and more recent breatharian [1979] 'a person who consumes no nutrients other than those absorbed from the air' $\leftarrow$ breath +-arian and flexitarian [1998] 'a person who follows a primarily but not strictly vegetarian diet' $\leftarrow$ flexible+-tarian. 
- -tel $(\leftarrow$ hotel) 'accommodation which functions as a hotel', as in motel [1925] 'a roadside hotel catering primarily for motorists' and boatel [1950] 'a ship or boat which functions as a hotel', acting as models for floatel [1959] 'a floating hotel' $\leftarrow$ float + -tel and apartotel [1965] 'a type of hotel which offers private suites for self-catering' $\leftarrow$ apartment +- tel.

- umentary ( $\leftarrow$ documentary) 'programme which has the characteristics of a documentary but also of another genre/subject', as in mockumentary [1965] 'a programme which adopts the form of a documentary in order to satirize its subject', and later rockumentary [1969] 'a documentary film on the subject of rock music' $\leftarrow$ rock + -umentary, and shockumentary [1970] 'a documentary film with shocking subject' $\leftarrow$ shock + -umentary. corpus we find additional instances, mainly nonce words or hapax legomena, which display the same splinters:

(38) According to Adelana, the chatbot contributes to facilitating and accelerating the process of providing information to market participants. (NOW, 2018)

(39) If you find you are little demotivated at work, do some deskercise or even go out for a brisk walk at lunch time. (NOW, 2018)

(40) Just like wearing a mankini wouldn't be appropriate in the office, there are some things that just aren't acceptable in and around your neighbourhood. (NOW, 2018)

(41) The policy may be translated to Taglish (Tagalog-English) or the local dialect, depending on the educational attainment of the majority. (NOW, 2018)

(42) Pushing China to change that model is a key goal of Trumponomics. (NOW, 2018)

(43) There is infotainment and advertainment and edutainment. Food, sports and retail have all embraced its possibilities. (NOW, 2018)

(44) High-tea options include vegan, gluten-free vegetarian, pescetarian, and dairy-free. (NOW, 2018)

(45) Other summer documentaries include "A LEGO Brickumentary," the story of a toy that became a subculture. (NOW, 2015) OED (-bot, -tainment) [cf. Bauer et al. 2013]. The splinter -ercise has also become productive in English, so much so that Baldi \& Dawar [2000: 968] have assigned it the label of "unconventional suffix". In their work, they also cite creative formations such as commutercize [n.d.] and computercize [n.d.] as novel derived words. Moreover, Adams [1973:170] describes -tarian as a "suffix" that occurs in a subgroup of words "inspired by vegetarian [1842] and having to do with "beliefs about diet". He also cites meatarian [n.d.] and sea-foodetarian [n.d.] [Adams 1973: 170] among additional examples, which cannot be considered mere blends, because their meaning involves reinterpretation of vegetarian not including 'vegetables'.

\subsection{General discussion}

The presence of frequent splinters in blend formation shows that a process of regularization is underway. This regularization does not involve the same generalization or abstraction as in rules, but it is regularization triggered by analogy. Analogy may be based on surface (i.e. phonological, morphotactic, and semantic) similarity between two words, such as smaze and smog, but also between one novel word 
(e.g. tankini) and a series of formations which constitute a schema (bikini, monokini, trikini, etc.). Unlike rules, a schema is a concrete template for novel formations.

From our analysis, it results that a schema model is especially functional in attributive or headed blends, where the first component (or variable part) qualifies or specifies the head. For instance, in -tarian formations, the first component specifies the type of diet restriction, e.g., to vegetables (vegetarian), fruit (fruitarian), nuts (nutarian), meat (meatarian), fish (pescetarian), seafood (sea-foodetarian), breathed air (breatharian), or flexible (flexitarian). Also blends that are apparently coordinate, such as apartotel, dancercise, docutainment, or Japlish, whose source words (i.e. apartment + hotel, dance + exercise, documentary + entertainment, Japanese + English) seem to have equally contributed to the meaning of the blend, are actually headed, in that the blends denote 'a type of hotel, exercise, entertainment' or 'a variety of English'. In other words, the right source word (or splinter) carries a greater semantic weight than the left one, in that it corresponds to the head of an equivalent compound. This greater semantic importance is linked to the process of secretion or specialization that leads splinters to develop into combining forms or secreted affixes.

Thus, in blending, there is often an evolution from splinter to combining form, or secreted suffix. In other words, when a splinter is frequently and productively used to coin a series of new words, it can be viewed as a regular combining form, or even as a suffix, especially if it is not only abbreviated but also involves a semantic reinterpretation. This evolution corresponds to a development from surface analogy, with a precise model word, to analogy via schema, with several prototype words which constitute a series and function as model for new formations, both neologisms and nonce words. Needless to say, not all nonce formations become lexicalized words, but the fact that they use an existing schema as model provides further stability to the pattern and may represent the first step towards productivity and rule.

\section{Conclusions}

The blending phenomenon is varied and hard to classify within morphological modules and theoretical frameworks. Many blends indeed display an extra-grammatical nature, with an unpredictable output, not transparently analyzable into existing morphemes, and source words that are difficult to recognize. The possible combinatory patterns of the source lexemes, the different portions that are retained in the resulting blend, and their semantic contribution to the overall meaning increase the number of variables and classificatory criteria for blends, thus decreasing predictability of the output given an input.

Unlike regular compounds, whose input is unambiguous and unequivocal, the input of blends is generally opaque, unclear, blurred, and difficult to reconstruct due to the missing word part(s). Unlike combining forms, whose regularity allows abstraction and generalization based on the secretion process, blends do not allow the same abstraction as in rules. These are some of the reasons why blends are often overlooked in morphological theories, relegated to extra-grammatical operations of word-creation, and confined in use to the fields of advertising and humorous literature. important in specialized domains, besides being used in familiar contexts; and 2) they 
mainly have a naming/labelling function, in other words, they are necessary either to fill a conceptual and/or lexical gap, the new name being often iconic of the referent's meaning, or to label novel products and trademarks.

A lexicographic investigation combined with a corpus-based analysis have shown that blending is growing as a word-formation process, with several new blends that are lexicalized, included in the OED, and attested in corpora of English with low to high frequency. A corpus-based study has supported the quantitative results, by showing the variety of contexts that are favourable to blending as a word-formation mechanism, as well as the functions that new blends can serve and the effects that they produce.

A data-driven approach has also shown that some new blends resemble existing ones. This suggests that blending may be triggered by analogy, although the two processes do not coincide. For instance, wargasm and ambisextrous are blends from war + orgasm and ambidextrous + sex, not "genuine analogical formations" coined after orgasm or ambidextrous [Bauer 1983:96]. The "phonetic resemblance" that Bauer [1983:96] mentions is just a consequence of the fact that wargasm and ambisextrous include in their form (and meaning) the words orgasm and ambidextrous. Hence, not all blends are analogical, only those which follow a concrete model are.

Analogical blends, indeed, are a particular type of blend displaying phonological, morphological, and semantic similarity with another word or series. For example, blaxploitation is analogically formed after the model word sexploitation because: phonologically, they share three syllables and a coda, morphologically, they are both obtained by blending two words, and semantically they refer to the exploitation of something or someone (sex/sexual material, black people) for commercial purposes. This multilevel resemblance between the two blends helps English speakers recognize the source lexemes of the new blend (black + exploitation), leads them to accept the new blend as part of their lexical stock, and encourages them to form similar blends in the likeness of the model.

Hence, this study has shown that analogy can provide some regularity to the blending process and increase predictability in the formation of novel blends, especially those based on a concrete schema model. For instance, novel blends such as Rogernomics, Obamanomics, and Trumponomics can be interpreted on the basis of the existing series Nixonomics, Reaganomics, Clintonomics, etc., which has given birth to the splinter (o)nomics referring to 'the economic policies of a President or head of state'. Frequent splinters such as -(o)nomics, -tainment, or -tarian ease source word recognizability, facilitate blend interpretation, and encourage speakers to adopt new blends in their vocabulary. Because of their frequency and productivity in the coinage of novel lexical blends, some blend splinters deserve the label of 'combining form'. In other words, some blends are unique instances of word-creation, others are part of productive wordformation. 


\section{BIBLIOGRAPHY}

ADAMS Valerie, 1973, An Introduction to Modern English Word-formation, London: Longman.

ARNDT-LAPPE Sabine \& PLAG Ingo, 2013, "The role of prosodic structure in the formation of English

blends", English Language and Linguistics 17, 537-563.

BALDI Philip \& DAWAR Chantal, 2000, "Creative processes”, in BOOIJ Geert E., LEHMANN Christian, MUGDAN Joachim, KESSELHEIM Wolfgang \& SKOPETEAS Stavros (Eds.), Morphologie-Morphology: An International Handbook of Inflection and Word-formation, Vol. 1, Berlin/New York: De Gruyter, 963-972.

BAT-EL Outi, 2006, “Blends”, in BROWN Keith (Ed.), Encyclopedia of Language and Linguistics, Oxford: Elsevier, 66-70.

BAUER Laurie, 1983, English Word-formation, Cambridge: Cambridge University Press.

BAUER Laurie, 2001, Morphological Productivity, Cambridge: Cambridge University Press.

BAUER Laurie, 2012, "Blends: Core and periphery", in RENNER Vincent, MANIEZ François \& ARNAUD Pierre J.L. (Eds.), Cross-Disciplinary Perspectives on Lexical Blending, Berlin/Boston: De Gruyter, 11-22.

BAUER Laurie \& HUDDLESTON Rodney, 2002, "Lexical word-formation", in HUDDLESTON Rodney \& PULLUM Geoffrey K. (Eds.), The Cambridge Grammar of the English Language, Cambridge: Cambridge University Press, 1621-1723.

BAUER Laurie, LIEBER Rochelle \& PLAG Ingo, 2013, The Oxford Reference Guide to English Morphology, Oxford: Oxford University Press.

BELIAEVA Natalia, 2014, “A study of English blends: From structure to meaning and back again”, Word Structure 7, 29-54.

BLANK Andreas, 2001, “Pathways of lexicalization”, in HASPELMATH Martin, KÖNIG Ekkehard, OESTERREICHER Wulf \& RAIBLE Wolgang (Eds.), Language Typology and Language Universals, Vol. 2, Berlin: De Gruyter, 1596-1608.

BooIJ Geert E., 2010, Construction Morphology, Oxford: Oxford University Press.

BRINTON Laurel J. \& TRAUGOTT Elizabeth C., 2005, Lexicalization and Language Change, Cambridge: Cambridge University Press.

CANNON Garland, 2000, "Blending”, in BOoIJ Geert E., LEHMANN Christian, MUGDAN Joachim, KESSELHEIM Wolfgang \& SKOPETEAS Stavros (Eds.), Morphologie-Morphology: An International Handbook of Inflection and Word-formation, Vol. 1, Berlin/New York: De Gruyter, 952-956.

COCA: Corpus of Contemporary American English, 1990-2017, https://corpus.byu.edu/coca/ (last accessed 07/04/2019).

CONNOLly Patrick, 2013, "The innovation and adoption of English lexical blends", JournaLIPP 2, $1-14$.

DRESSLER Wolfgang U. \& TUMFART Barbara, 2017, "New corpus-linguistic approaches to the investigation of poetic occasionalisms: The case of Johann Nepomuk Nestroy", in DZIUBALSKAKOŁACZYK Katarzyna (Ed.), Yearbook of the Poznań Linguistic Meeting 3, 155-166. 
DRESSLER Wolfgang U., 2000, "Extragrammatical vs. marginal morphology", in DOLESCHAL Ursula \& THORNTON Anna M. (Eds.), Extragrammatical and Marginal Morphology, München: Lincom Europa, $1-10$.

FRADIN Bernard, 2000, "Combining forms, blends and related phenomena", in DOLESCHAL Ursula \& THORNTON Anna M. (Eds.), Extragrammatical and Marginal Morphology, München: Lincom Europa, 11-59.

GRIES Stefan Th., 2004, “Isn't that fantabulous? How similarity motivates intentional morphological blends in English", in ACHARD Michel \& KEMMER Suzanne (Eds.), Language, Culture, and Mind, Stanford, CA: CSLI, 415-428.

HоскETT Charles F., 1967, "Where the tongue slips, there slip I", in HALLE Morris (Ed.), To Honor Roman Jakobson, The Hague: Mouton, 910-936.

KEMMER Suzanne, 2003, "Schemas and lexical blends", in CUYCKENS Hubert C., BERG Thomas, DIRVEN René \& PANTHER Klaus-Uwe (Eds.), Motivation in Language: From Case Grammar to Cognitive Linguistics. Studies in Honour of Günter Radden, Amsterdam/Philadelphia: Benjamins, 69-97.

KÖPCKE Klaus-Michael, 1993, Schemata bei der Pluralbildung im Deutschen: Versuch einer kognitiven Morphologie, Tübingen: Gunter Narr Verlag.

LEHRER Adrienne, 1996, "Identifying and interpreting blends: An experimental approach", Cognitive Linguistics 7(4), 359-390.

LEHRER Adrienne, 2007, “Blendalicious”, in MUNAT Judith (Ed.), Lexical Creativity, Texts and Contexts, Amsterdam/Philadelphia: Benjamins, 115-133.

MATTIELLo Elisa, 2013, Extra-grammatical Morphology in English. Abbreviations, Blends, Reduplicatives, and Related Phenomena, Berlin/Boston: De Gruyter.

MATTIELlo Elisa, 2017, Analogy in Word-formation. A Study of English Neologisms and Occasionalisms, Berlin/Boston: De Gruyter.

MATTIELlo Elisa, 2018, "Paradigmatic morphology: Splinters, combining forms, and secreted affixes", SKASE Journal of Theoretical Linguistics, 15(1), 2-22, also available http://www.skase.sk/ Volumes/JTL36/pdf_doc/01.pdf

MILROY James, 1992, Linguistic Variation and Change. Oxford: Blackwell.

NOW: News on the Web, 2010-2018, https://corpus.byu.edu/now/ (last accessed 01/01/2019).

OED2-3: Oxford English Dictionary Online, 1989-2019, $2^{\text {nd }} / 3^{\text {rd }}$ ed. Oxford: Oxford University Press, http://www.oed.com/ (last accessed 10/10/2018).

PLAG Ingo, 1999, Morphological Productivity: Structural Constraints in English Derivation, Berlin/New York: De Gruyter.

RENNER Vincent, 2006, Les composés coordinatifs en anglais contemporain, Lyon: Université Lumière Lyon 2 dissertation.

RENNER Vincent, MANIEZ François \& ARNAUD Pierre J.L., 2012, Cross-Disciplinary Perspectives on Lexical Blending, Berlin/Boston: De Gruyter.

RONNEBERGER-SIBOLD Elke, 2006, "Lexical blends: Functionally tuning the transparency of complex words", Folia Linguistica 40(1-2), 155-181. 
RONNEBERGER-SIBOLD Elke, 2010, "Word creation: Definition - function - typology", in RAINER Franz, DRESSLER Wolfgang U., KASTOVSKY Dieter \& LUSCHÜTZKY Hans C. (Eds.), Variation and Change in

Morphology, Amsterdam/Philadelphia: Benjamins, 201-216.

THORNTON Anna M., 1993, "Italian blends", in TONELli Livia \& DRESSLER Wolfgang U. Eeds.), Natural

Morphology. Perspectives for the Nineties, Padova: Unipress, 143-155.

THORNTON Anna M., 2004, "Parole macedonia”, in GROSSMAN Maria \& RAINER Franz (Eds.), La

formazione delle parole in italiano, Tübingen: Niemeyer, 567-571.

\section{NOTES}

1. The dates in brackets refer to the earliest attestation of the words in the OED. See Beliaeva [2014] for an in-depth study of the phonological and structural differences between blends and clipping compounds.

2. The remaining 53.5\% blends display a corpus frequency between 0.01 and $0.09 \mathrm{pmw}$.

\section{ABSTRACTS}

This study investigates lexical blending from a synchronic perspective, with special focus on new blends in English. It analyses a sample of 245 English blends dated 1950-2010, from both quantitative and qualitative viewpoints, with the purpose of reassessing the importance of the blending phenomenon in terms of 1 ) its suitability in the coinage of new specialized vocabulary, and 2) its regularity in the creation of words containing frequent splinters. From the theoretical viewpoint, the study contributes to the issue of whether blending should be considered an extragrammatical phenomenon of word-creation or a regular process of word-formation. It supports the claim that while some blends (e.g. glam-ma $\leftarrow$ glamour + grandma) are unique instances, others are part of series (e.g. eatertainment, irritainment, shoppertainment, all obtained from the splinter tainment $\leftarrow$ entertainment), and therefore show a tendency towards greater regularity and productivity. The goal of the study is fourfold. First, it aims at identifying the contexts/registers which favour the formation of blend words, ranging from slang/colloquial registers to specialized domains. Second, this study addresses the question of whether blends are created with the intention of designating a new referent or to give a new name to an existing referent. Third, the study focuses on a particular type of blending, called 'attributive' or 'headed', which displays an endocentric relation with its head, as in rockumentary $(\leftarrow$ rock + documentary) and Clintonomics ( $\leftarrow$ Clinton + economics). In particular, some attributive blends will be viewed as possible schema models for new lexical blends, with the second splinter -umentary and -(o)nomics as potential combining forms or secreted affixes for novel formations.

Cette étude examine l'amalgame lexical dans une perspective synchronique. En particulier, elle analyse une collection de 245 nouveaux mots-valises en anglais, sur la période 1950-2010, d'un point de vue quantitatif et qualitatif. Cette étude a pour objectif de réévaluer l'importance de l'amalgame 1) pour inventer un nouveau lexique spécialisé, et 2) pour créer des mots qui contiennent des fractomorphèmes réguliers. D'un point de vue théorique, l'étude tente de répondre à la question suivante : l'amalgame est-il un phénomène extra-grammatical de création 
de mot ou un procès régulier de formation de mot? L'étude affirme que certains mots-valises sont des cas uniques (p.ex. glam-ma $\leftarrow$ glamour + grandma), tandis que d'autres font partie de séries de mots (p.ex. eatertainment, irritainment, shoppertainment viennent du fractomorphème tainment $\leftarrow$ entertainment) et tendent vers la régularité et la productivité. L'étude a quatre objectifs. D'abord, elle vise à montrer les contextes/registres qui privilégient la formation des mots-valises, et qui vont du langage familier au langage de spécialité. Deuxièmement, l'étude vise à répondre à la question suivante : les mots-valises sont-ils créés pour designer de nouveaux référents ou pour donner un nouveau nom à un référent existant? Troisièmement, l'étude se concentre sur l'amalgamation dite 'attributive' ou 'endocentrique', comme rockumentary ( $\leftarrow$ rock + documentary) et Clintonomics ( $\leftarrow$ Clinton + economics). Les mots-valises attributifs sont décrits comme des modèles possibles ou schémas pour les nouveaux amalgames lexicaux, dont les seconds fractomorphèmes -umentary et -(o)nomics sont des affixes secrétifs potentiels pour de nouveaux mots.

\section{INDEX}

Mots-clés: mots-valises attributifs, nouveaux mots, néologismes, anglais, fractomorphème, affixes secrétifs, schéma

Keywords: attributive blends, new words, neologisms, English, splinters, secreted affixes, schema

\section{AUTHOR}

\section{MATTIELLO ELISA}

University of Pisa

elisa.mattiello@unipi.it 